\title{
Gestão 2008-2009: adaptando o crescimento à realidade
}

\author{
2008-2009 management: adapting growth to reality
}

\author{
Flávio Shansis, Paulo Oscar Teitelbaum*
}

* Editores, Rev Psiquiatr RS, gestão 2008-2009.

Este é o primeiro número da gestão que passa a ser responsável pelos rumos da Revista de Psiquiatria do Rio Grande do Sul pelos próximos dois anos.

Desde o seu surgimento, cada gestão pôde implementar com capacidade criadora sua forma de gerenciar a revista. Acreditamos, no entanto, que foi justamente a mescla entre a experiência dada pela continuidade do trabalho de uma gestão para outra e a renovação trazida pela alternância de comando o fator responsável pelo desenvolvimento importante de nossa revista. Nós não faremos diferente.

Estamos cientes do crescimento exponencial da Rev Psiquiatr RS. Nas últimas três gestões, o número de artigos recebidos aumentou em $269 \%$. Somado a isso, a Revista permanece sendo Qualis A nacional pelos critérios da Coordenação de Aperfeiçoamento de Pessoal de Nível Superior (CAPES), mantém sua edição bilíngüe em português e inglês no SciELO internacional, adaptou seu índice de recusa de artigos para cerca de $60 \%$, ampliou e modificou seus conselhos editoriais local, nacional e internacional e definiu sua linha editorial como prioritária a artigos originais. Além disso, seguindo os mais modernos padrões entre periódicos científicos, adquiriu e implantou um sistema de submissão e gerenciamento de artigos totalmente informatizado, via internet, o que ampliou e facilitou enormemente o acesso de autores interessados em publicar, bem como reduziu drasticamente os prazos entre submissão do artigo e sua publicação.

Tudo isso, obviamente, será mantido.

A atual gestão da Rev Psiquiatr RS, contudo, precisa haver-se com as conseqüências desse crescimento e o seu gerenciamento. Em especial, na sua adaptação à realidade econômica.

Gerenciar e publicar uma revista científica bilíngüe em nosso país é algo extremamente dispendioso. Há 4 anos, por uma sábia decisão da diretoria da Sociedade de Psiquiatria do Rio Grande do Sul (SPRS), a Rev Psiquiatr RS passou a ser enviada gratuitamente a todos os psiquiatras sócios da Associação Brasileira de Psiquiatria (ABP), além do envio que já ocorria aos sócios da SPRS.

O objetivo, à época, era tornar nossa Revista reconhecida nacionalmente, ampliar o universo de autores e, com isso, trazer novos e melhores artigos. Os dados já citados acima atestam a correção daquela atitude. Cinco anos passados, no entanto, e com novidades no campo editorial (como, por exemplo, a aceitação pela comunidade científica internacional das publicações eletrônicas), a Rev Psiquiatr RS decide seguir o rumo dessa nova tendência editorial. Assim, a partir do próximo número, nossa revista voltará a ser enviada na sua forma impressa apenas aos sócios da SPRS, mantendo uma tradição de 29 anos ininterruptos. O formato eletrônico, no entanto, será de acesso livre e universal, incluindo todo o conteúdo da revista tanto na língua portuguesa quanto na língua inglesa.

A Rev Psiquiatr RS, distribuída gratuitamente a quase 5.000 psiquiatras brasileiros na sua forma impressa, trouxe nossa revista a um patamar de qualidade científica e reconhecimento nacional que nunca antes obtivera. É chegada a hora de adaptá-la à realidade financeira, de encerrar um ciclo e dar início a outro.

A SPRS, através das últimas diretorias, possibilitou esse crescimento da revista, investindo decidida e pesadamente. Com satisfação, pensamos que, tal como no ciclo vital, nesta nova etapa, a Rev Psiquiatr RS poderá seguir seus rumos sem a necessidade do intenso e constante amparo financeiro da instituição à qual pertence. A filha já pode seguir sozinha: cresceu bem, forte e respeitada. Saberá se cuidar, dizem seus pais orgulhosos.

Portanto, por um lado, embasados nas experiências anteriores de continuidade, seguimos bebendo nos acertos de todas as gestões que nos antecederam. Por 
outro, contribuímos com nossa decisão ao somarmos à publicação impressa uma outra totalmente eletrônica.

Esse é o início de nossa gestão. Uma nova etapa com novos desafios.
Esperamos, juntamente com os colegas do Conselho Editorial, superar esses desafios e contribuir com nossa revista nesse biênio que nos espera. 